\title{
Improving Outcomes of Underrepresented College Students Through Community- Engaged Employment
}

Anthony J. Schulzetenberg

University of Minnesota, USA

Yu-Chi Wang

University of Minnesota, USA

Ashley Hufnagle

University of Minnesota, USA

Krista M. Soria

University of Minnesota, USA

Geoffrey Maruyama

University of Minnesota, USA

Jason Johnson

University of Minnesota, USA

\section{Recommended Citation:}




\title{
Improving Outcomes of Underrepresented College Students Through Community-Engaged Employment
}

\author{
Anthony J. Schulzetenberg \\ Yu-Chi Wang \\ Ashley Hufnagle \\ Krista M. Soria \\ Geoffrey Maruyama \\ Jason Johnson \\ University of Minnesota, USA
}

\begin{abstract}
Although volunteer community engagement has been recognized as promoting positive academic outcomes among college students, such experiences can be impractical for underrepresented students who often need to work. Community-engaged employment offers paid opportunities for students to earn money while participating in meaningful community initiatives. In this study, we explored the impact of community-engaged employment on the academic outcomes of underrepresented students. We created a comparison group using propensity score matching, which reduced selection bias and group differences on background characteristics, thus strengthening causal arguments. Results showed that underrepresented students who were employed in a community-engaged work program had significantly higher second-year retention rates, graduation rates, grade point averages, and number of credits completed compared to similar students not employed in the program. These findings indicate that community-engaged employment can provide positive academic outcomes similar to volunteer community engagement experiences, while also addressing financial barriers that many underrepresented students encounter.
\end{abstract}

Keywords: academic achievement, community engagement, employment, higher education, underrepresented students

\section{Mejora de los resultados académicos en estudiantes universitarios infrarrepresentados a través de empleos comprometidos con la comunidad}

A pesar de que se reconoce que la participación comunitaria voluntaria promueve resultados académicos positivos entre los estudiantes universitarios, estas experiencias pueden resultar no muy prácticas para los estudiantes infrarrepresentados, quienes a menudo necesitan trabajar. Los empleos comprometidos con la comunidad ofrecen oportunidades pagadas para que los estudiantes ganen dinero al mismo tiempo que participan en iniciativas comunitarias significativas. En este estudio, exploramos el impacto que tienen los empleos comprometidos con la comunidad en los resultados académicos de estudiantes infrarrepresentados. Para ello, creamos un grupo de comparación utilizando el pareamiento por puntaje de propensión ('propensity score matching' o 'PSM' en inglés), lo que redujo el sesgo de selección y las diferencias de grupo basadas en el entorno social, fortaleciendo así los argumentos causales. Al comparar los resultados académicos de estudiantes infrarrepresentados empleados en programas de participación comunitaria con estudiantes similares no empleados en dichos programas, observamos que tanto la tasa de retención en el segundo año de estudios, como la tasa de graduación, los promedios de calificaciones y el número de créditos completados fueron significativamente más altos en los primeros. Estos hallazgos indican que el empleo comprometido con la comunidad puede proporcionar resultados académicos positivos similares a las experiencias de participación comunitaria voluntaria, al tiempo que ofrece una solución a las barreras financieras que enfrentan muchos estudiantes infrarrepresentados.

Palabras clave: resultados académicos, participación comunitaria, empleo, educación superior, estudiantes infrarrepresentados.

Editors' Note: Translation by Beatriz Calvo-Peña Department of English and Foreign Languages Barry University, USA 
A renewed emphasis within universities and colleges to foster active and socially responsible citizens has spurred calls for increased community engagement programs and practices in higher education institutions (Hollister et al., 2008; Palmer, 2007; Warren, 2005). Community engagement has been cited as a vehicle for instilling civic responsiveness (Schamber \& Mahoney, 2008; Steinberg et al., 2011) as well as improved academic outcomes (Astin et al., 2000). The extant engagement literature, however, provides little information about the benefits of community engagement for underrepresented students - a group that includes students of color, first-generation students, and low-income students. Further, even though scholars have studied the many benefits of community engagement, they have not yet studied whether paid opportunities to engage in local community service initiatives, herein referred to as communityengaged employment, can offer similar benefits.

Community-engaged employment opportunities can provide college students with opportunities for engagement in local communities in ways that support their desire to "give back" while also supplementing their income. Traditional community engagement opportunities such as volunteerism or community service may not be a viable option for many students who need to work to pay their tuition and/or cover their living expenses. Indeed, large numbers of undergraduate students are employed while attending college: In 2017, $81 \%$ of part-time students were employed and $43 \%$ of full-time students were employed (McFarland et al., 2019). Approximately $27 \%$ of full-time students were employed over 20 hours per week while $71 \%$ of parttime students were employed over 20 hours per week (McFarland et al., 2019), suggesting that substantial numbers of college students may not have the time in their schedules to dedicate to volunteer community engagement. Furthermore, volunteerism opportunities may be limited for students who need to care for family members or dependents, or for those who encounter structural barriers to participation (e.g., scheduling, transportation).

In particular, community engagement opportunities like volunteerism may be out of reach for students who are low-income, working-class, students of color, and first-generation college students - all of whom are all more likely to work a greater number of hours while enrolled, live off campus, and commute longer hours to campus (Longwell-Grice \& Longwell-Grice, 2007-2008; Martinez et al., 2009; Soria et al., 2014). The aforementioned groups of students are more likely than their peers to withdraw from college before earning their college degrees (Soria, 2015). Although community service has been associated with increased retention and graduation rates (Berger \& Milem, 2002; Soria et al., 2012; Song et al., 2017; Ting, 2000; Yue \& Hart, 2017), structural barriers related to income and employment may mean that the underrepresented students who are most at risk for dropping out of college cannot reap the benefits of community service.

For underrepresented and marginalized students, one possible practical alternative to volunteer community engagement is community-engaged employment; however, research on paid community engagement is lacking. To address this gap, we aim to understand how community-engaged employment opportunities might impact underrepresented college students' academic outcomes. Specifically, we focus on the effects of this type of community engagement for underrepresented students. We hypothesize that community-engaged employment results in academic benefits similar to those of volunteer community engagement, while providing much-needed income for economically needy students.

\section{Community Engagement and Higher Education}

The earliest public universities in the United States were founded under the premise that they would produce highly skilled professional workers, research that benefits the American people, and knowledge that helps build a strong democratic society (Fitzgerald et al., 2016). Related to these values, educational institutions were designed to provide students with skills, knowledge, and perspectives, which might benefit society. In modern higher education, attempts to maintain these values and promote active citizenship have been the focus of community engagement programs that aim to teach students civic-mindedness (Bringle \& Steinberg, 2010), produce graduates who are attuned to societal needs, and encourage students to become active within their communities (Weiler et al., 2013). Under the supervision of higher education institutions, 
students collaboratively work with organizational partners to co-create solutions and meet communityidentified needs (Altman, 1996). In this way, institutions can promote learning, discovery, and societal enrichment, and communities can inform discovery and strengthen connections between classroom learning and real-world applications.

Partnerships between institutions and community members provide the framework for community engagement. The nature of the partnerships can be diverse, reflecting the unique ways students can engage with societal issues and serve communities while drawing on their curricular materials. In service-learning, community service is directly connected to the classroom curriculum. Other forms of engagement are less formally tied to course content, such as those in which students participate in community service activities facilitated by the university or an affiliate that are designed to enhance students' learning and civic responsibility while fulfilling a community need.

Literature broadly supports positive outcomes for students who engage with communities through service, including increased retention (Kuh et al., 2005), improved academic outcomes (Song et al., 2017), greater levels of socially responsible leadership (Soria et al., 2013), and enhanced civic engagement (Mitchell et al., 2011). However, research on community-engaged employment that provides similar experiences as volunteer community engagement — but with the added benefit of a wage - is lacking. Community-engaged employment and volunteer community engagement seemingly should elicit similar academic benefits for students because both types of opportunities help build relationships and develop connections between academic learning and real-world applications. Further, students who participate in community-engaged employment typically choose their employment, which would suggest that they may have the same motivations as those who participate in community engagement activities, especially when it comes to the meaningful nature of the work and the potential for the impact of their contributions (Mesch, et al., 1998). For instance, individuals who participate in volunteer programs such as AmeriCorps and receive stipends as remuneration for their time spent volunteering are most likely to cite altruism as their motivation for participation (Tschirhart et al., 2001).

Community-engaged employment may also be particularly impactful for underrepresented students, who often feel a lack of belonging and encounter negative academic stereotypes in higher education (Steele \& Aronson, 1995; Walton \& Cohen, 2007). Students who participate in community service have a higher sense of belonging compared to students who do not (Soria et al., 2012), which could extend to communityengaged employment. In particular, community-engaged employment that includes mentoring and tutoring community youth, much like that explored in the present study, could have benefits similar to those experienced in service-learning courses, including higher scores on measures of civic attitudes, self-esteem, interpersonal and problem-solving skills, political awareness, and civic action (Weiler et al., 2013).

Building on what we know from the community engagement literature, we aim to examine the effects of community-engaged employment on underrepresented students' academic outcomes. While communityengaged employment could take the form of a range of activities, for the purposes of this study, it is defined as paid opportunities with community partners that allow students to apply their skills and knowledge in ways that directly address a community need while fostering connections between students' work, education, and university. Community-engaged employment experiences differ from employment experiences that are not intended to promote community engagement; community-engaged employment is specifically designed to encourage personal growth and positive social interactions for students through engagement with external communities addressing their challenges.

We partnered with a local organization that provides extracurricular activities to engage college students. The activities typically complement employment for undergraduate students that has them tutor and mentor local middle-school youth from diverse backgrounds in an after-school program. The offcampus program hires primarily underrepresented college students to work with youth from similar backgrounds as themselves. A critical component of this program, and of the organization's overall mission, is that it is designed to be mutually beneficial for university students, the communities and youth they serve, and the staff with whom they collaborate. The program was carefully designed to consider both the tutees' and the tutors' development. In the context of this program, students are given opportunities to build camaraderie with fellow mentors and tutors and to apply their knowledge and skills to help community 
members. Through serving in the community, university students can share their talents and knowledge in ways that produce purposeful and observable results.

One common challenge in evaluating academic outcomes of students participating in a program offered by an organization external to a college or university is that the organization does not have access to institutional records on program participants, let alone for any type of comparison group. Therefore, we developed strategic community-university partnerships to address this challenge. Generally, communityuniversity partnerships are associated with forming authentic relationships between communities and institutions of higher learning (Holliday et al., 2015). Past research teaches us that top-down approaches and power imbalances can sometimes leave community partners with negative perceptions of the university system (Maurrasse, 2002; Strier, 2010; Suarez-Balcazar et al., 2005). However, there are also examples of successful community-university partnerships that employ a bottom-up strategy in which the community and university work together to develop shared goals (Cooper et al., 2014; Sandy \& Holland, 2006). Thus, our community-university partnership was guided by the latter and focused on using university resources to achieve objectives mutually agreed upon by the university and community partners (Holliday et al., 2015). Importantly, this approach allowed both partners to answer questions that they would not have been able to effectively answer alone. Additionally, our community partners benefitted by being able to quantify the impact of their program by explicitly connecting program participation to students' academic outcomes.

More specifically, in this study, we partnered with the university's Institutional Research office, which agreed to provide de-identified achievement and demographic data to us for both participants (using information provided by the external program) and their peers so we could create a matched comparison group and examine long-term academic outcomes.

To investigate the effects of community-engaged employment on underrepresented students' academic outcomes, we developed the following research questions:

- Is community-engaged employment associated with underrepresented students' persistence in college?

- Is community-engaged employment associated with underrepresented students' graduation rates?

- Is community-engaged employment associated with underrepresented students' academic performance in college?

\section{Conceptual Frameworks}

With these questions and considerations in mind, we rooted our study in Bean and Eaton's (2001) retention model to help explain how community-engaged employment may potentially help reduce some of the unique obstacles that underrepresented students encounter. Broadly speaking, Bean and Eaton's model of retention indicates that students' background experiences and characteristics upon arrival to campus influence their initial institutional/environmental interactions. The institutional interactions then spur iterative psychological processes that lead to intermediate outcomes of social and academic integration. Students' perceived level of academic and social integration sets the stage for the attitudes, intentions, and behaviors that ultimately determine students' persistence and retention outcomes.

Bean and Eaton (2001) believed that social interactions, such as those that occur within the context of community engagement experiences, can increase engagement of students in the classroom while cultivating a sense of ownership of the communities in which they engage. Applying classroom knowledge to real-world needs outside the confines of academia is predicted to improve feelings of control over one's fate (i.e., an internal locus of control). For underrepresented students, self-perceptions that they are effective in their new social environment, in charge of their academic outcomes, and feeling as though they belong and fit in at their college could make the difference between staying in school and leaving.

The importance of community engagement for underrepresented students is further supported by Bronfenbrenner's (1994) widely used ecological models of human development. Bronfenbrenner postulated that the overlap of the predominant settings/environments in one's life is important for development and can support outcomes such as academic success. He argued that, in order to understand human development, one must consider the complete environment in which youth live and in which 
learning and development occur. Students are influenced by each of their immediate environments, by linkages and processes taking place between the different environments (e.g., how the university environment compares to the home or community), and by the overarching societal patterns of culture. According to Bronfenbrenner (1994), lack of alignment of different systems or cultures in a person's life can cause difficulty for the individual in determining how to think or behave. Acknowledging interactions between these contexts/environments (such as students' university campuses and their home communities) provides a framework for understanding how community-engaged employment may help to tie together those environments in new and constructive ways.

Students from backgrounds dissimilar to those of traditional post-secondary education students may find their colleges and universities confusing or unwelcoming places and are more likely to have a challenging time adjusting to their new environment and college life (Figueroa \& Hurtado, 2014; Hurtado, et al., 1996). Their adjustment during life transitions affects factors known to be related to persistence and graduation-namely, engagement (i.e., their personal or cognitive investment in tasks, culture, and situations) and sense of belonging (Hurtado \& Carter, 1997; Pittman \& Richmond, 2008). Engaging with a community outside the academic institution could provide the overlap needed to create alignment between the two disparate cultures through meaningful social interactions.

In sum, this background has focused on a model of college retention and a model of environmental coherence and fit. These conceptual bases (the model of retention and the ecological models of human development) have provided a context for much work with college students in the service-learning literature (Levine \& Cureton, 1998; Zlotkowski \& Duffy, 2010).

\section{Methodology}

Using archival data from the university's Office of Institutional Research, we analyzed the relationship between participation in community-engaged employment and academic outcomes for underrepresented students. Our partner organization provided participation information on over 300 student participants from 2010 to 2015 to our Institutional Research partner, who matched these participants with their academic records. Institutional Research staff then provided us with a dataset of background characteristics and academic outcomes for over 50,000 students enrolled at the university during 20102015, indicating which students had participated in the community-engaged employment program. This dataset included demographic measures and academic outcomes - specifically, cumulative grade point average (GPA), cumulative credits earned, semesterly enrollment status, and whether or not the student graduated within 6 years. By having this large pool of potential comparisons, we were able to employ a between-subjects quasiexperimental design by creating a matched comparison group through propensity score matching techniques described in the data analysis section below.

\section{Sample}

For this study, we analyzed data on first-year, nontransfer participants from six different entering cohorts $(2010,2011,2012,2013,2014$, and 2015). We focused our analyses on students who participated in the community-engaged employment program during their first year of enrollment to minimize bias when matching comparison students. By selecting first-year participants, we could consider the entering firstyear class as possible comparison individuals, and there was maximal time for participation to have an effect on the students' GPA, credits completed, persistence, and graduation. That is, first-year participants provide the longest timeframe to track longer-term differences in performance that may have been affected by the "treatment" of participation in community-engaged employment.

A total of 321 nontransfer, first-year undergraduate students participated in the community-engaged employment experience during 2010-2015. Our analyses included only a subset of students who met our definition of underrepresented, which includes students of color, first-generation college students, and/or those who received a Pell grant (indicating low-socioeconomic status). We included students who reported that they were Asian American because the university in this study has a high population of Hmong students, an ethnic group that experiences marginalization in education (e.g., Vang, 2005). 
After we selected only underrepresented participants and their matches, our total sample included 432 underrepresented students. The final treatment sample was 216 participants. That sample was $65 \%$ firstgeneration, 73\% Pell grant recipients, 29.6\% Asian or Pacific Islander, 2.3\% American Indian, 23\% Black, and $6.5 \%$ Hispanic. The 216 matched comparison students were $65 \%$ first-generation, $74.5 \%$ Pell grant recipients, 26\% Asian or Pacific Islander, 1.4\% American Indian, 24\% Black, and 7.4\% Hispanic. Across the years of participation, $39.8 \%$ of all students were from the fall 2010 entering first-year cohort, $2.3 \%$ from 2011, 5.1\% from 2012, 15.7\% from 2013, 22.2\% from 2014, and 14.8\% from 2015.

\section{Data Analysis}

We used propensity score matching techniques to create a matched comparison group from those who never participated in this community-engaged employment program. This was to assess the effects of participation in this community-engaged employment experience (referred to as "treatment" in the following section). To the extent that groups differ on variables aside from the treatment, those variables, if uncontrolled, could lead to misinterpretation of findings. The purpose of propensity score matching is to reduce selection bias in quasi-experimental studies and, therefore, strengthen causal arguments.

In accordance with the U.S. Department of Education's What Works Clearinghouse (WWC, 2017) standards and based on the recommendations of Austin (2011), we included covariates that we believed to be theoretically and/or practically related to participation in this type of program and/or to the academic outcomes we were assessing in this study. Furthermore, we did not include any covariates that were potentially influenced by participation in the treatment or obtained after the treatment occurred. We were also guided by previous research using propensity score matching to investigate the relationship between service-learning on educational outcomes (i.e., Song et al., 2017). Finally, as WWC specifies, analyses that include academic achievement as an outcome variable must also include prior achievement as a covariate. Therefore, we included composite ACT scores (or converted SAT scores to the ACT scale using ACT-SAT concordance) as a matching covariate as well as a measure of family economic background (in our case, Pell eligibility).

We utilized Johnson's (2018) R program functions, which call upon the MatchIt (Ho, et al., 2011), Optmatch (Hansen \& Klopfer, 2006), and Matching (Sekhon, 2011) packages. First, a logistic regression model was fit to evaluate an individual's likelihood of participation in the treatment. The model was significant, ${ }^{2}(22)=226.757, p<.001$, explaining $12.7 \%$ (Nagelkerke $\mathrm{R}^{2}$ ) of the variance in participation and correctly classified $98.5 \%$ of the cases (see Appendix A for table of regression weights). Using the regression weights, we created a propensity score for each treatment and potential comparison individual. The propensity score, which represents the probability of being in the treatment group, is created using background characteristics that are thought to potentially influence academic outcomes as well as a student's participation in the program (e.g., Rosenbaum, 2010; Stuart, 2010). We then matched students in the treatment group with students from the potential comparison group based on similar propensity scores using one-to-one matching. The students matched with each treatment case became the comparison group for the analyses.

Several measures were carried out to avoid violating the stable unit treatment value assumption (SUTVA) of propensity score methods. First, we performed exact matches on students' year of entry (new first-year students only were included in the sample). This means, for example, those who started in 2015 were matched with only other students who also started in 2015. By doing so, we reduced potential biases that could arise when looking at outcomes that are time sensitive such as graduation and credits earned. Exact matching on enrollment year also allowed us to include a larger proportion of the sample instead of capping inclusion criteria to students who were first enrolled 6 years from the most recent data available. Second, we defined our treatment condition as students who participated in the community-engaged employment program in their first year of enrollment. (Beyond the first year, dosage of program participation was not considered in this study.) These students were compared to students who never participated in the community-engaged employment program during the years in which data were used in this study. 
Our propensity matching variables (called conditioning variables) included prior achievement (composite ACT score), first-generation status, family income/socioeconomic status (Pell grant status), gender, race (with dummy variables), college of enrollment (using dummy variables), age, honors program status, and citizenship status. The goal was to create a comparison group that mirrored the treatment group on impactful variables, such that the only difference between the groups ideally consisted of whether or not they participated in the community-engaged employment experience.

Propensity score matching also assumes that there are initial imbalances between the treatment and comparison groups. Thus, we first looked across the groups to determine if there were, in fact, differences between the treatment group and the entire potential comparison group. The treatment group and the comparison group did differ on the background variables before matches were created, which provided justification for the use of the propensity score design. Specifically, the standardized mean differences between groups for each variable were more than 0.25 in 7 of the 17 different controlling variables included before matching. Utilizing the cutoff point of 0.25 standardized mean differences as a measure of difference between groups is in accordance with recommended practices to assess imbalance (Austin, 2011; Harder et al., 2011).

Within the propensity score matching technique, there are multiple methods available to produce matched sets (e.g., nearest neighbor, optimal pair matching, full matching, inverse weighting, and optimal pair matching comparing Mahalanobis distances). The different methods can improve match balances and decrease differences between groups, depending on the dataset. Currently, literature on which propensity score matching method to use to provide the most accurate results remains unclear, as there are few concrete guidelines about best practices; however, according to Austin (2011), different estimation and application techniques are more or less appropriate based on the specific study. Thus, Austin recommended that researchers check multiple methods for the balance of covariates before selecting a technique to proceed with outcome analysis. After checking the covariate balances, we proceeded with optimal pair matching, because it provided the closest distributions of propensity scores between groups, small differences in propensity score distances between matched pairs, and the best balances on background covariates after matching. Following the logistic regression analyses used to create propensity scores, we created a matched comparison group using optimal pair matching. The matches we created using this technique displayed between-group differences smaller than 0.25 standardized mean differences on all conditioning variables. Falling below this threshold supports our use of propensity score matching for these data.

We conducted diagnostic checks to ensure the matching technique used produced balanced and strong matches with the treatment group. First, we examined the distributions of propensity scores of the two groups. We compared the distributions of propensity scores before (Figures 1 and 2) and after matching (Figures 3 and 4). Before matching, the distributions of propensity scores were not similar, indicating the two groups differed on the variables included. After matching using the optimal pair matching technique, the propensity scores of the treatment and comparison groups showed no differences.

\section{Figure 1}

Histogram of Propensity Scores for Treatment and Comparison Before Matching
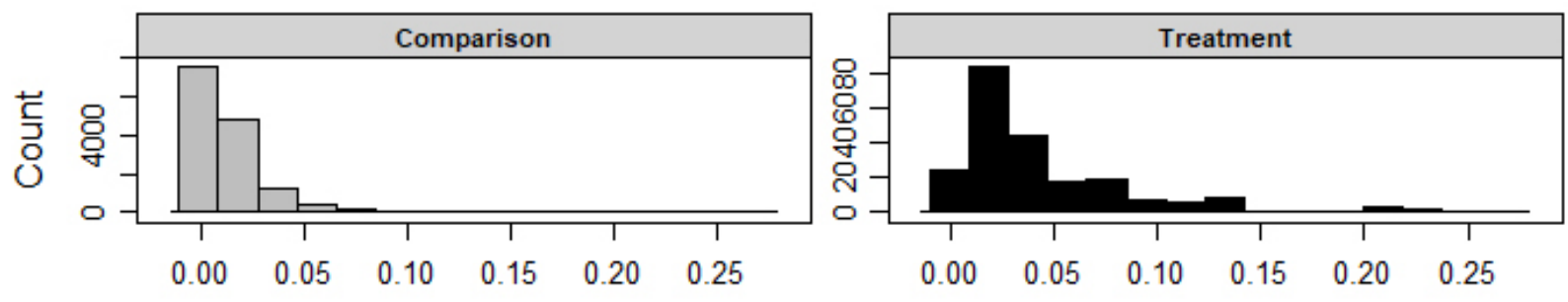

PSM Scores 
Figure 2

Density Plot of Propensity Scores for Treatment and Comparison Before Matching

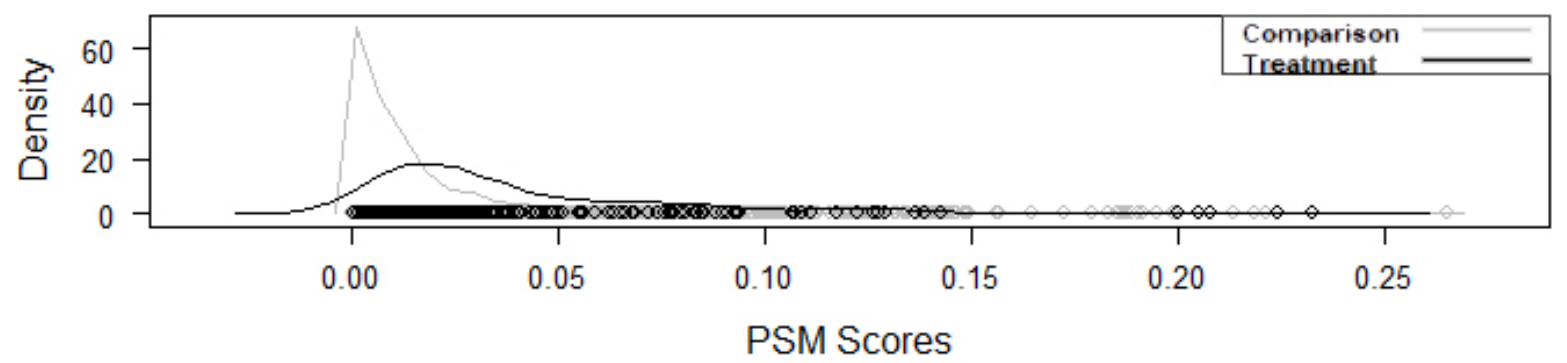

Figure 3

Histogram of Propensity Scores for Treatment and Comparison After Matching

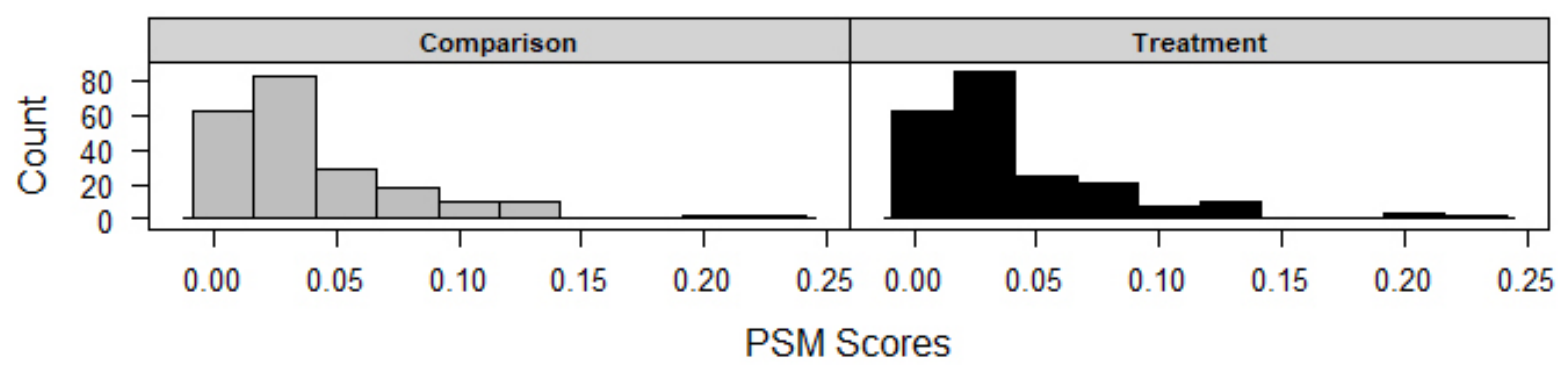

Figure 4

Density Plot of Propensity Scores for Treatment and Comparison After Matching

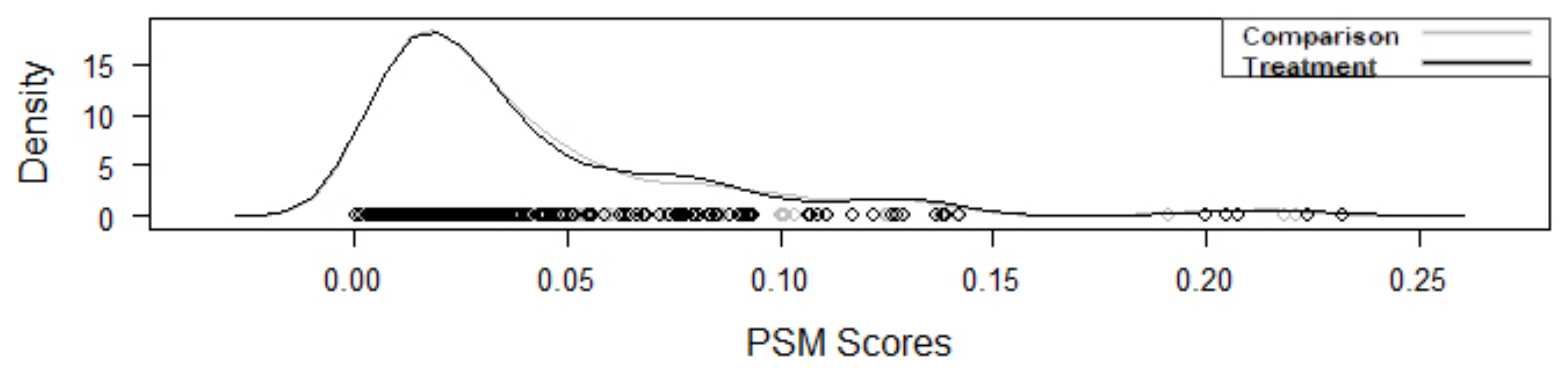

Second, we extracted the treatment and matched comparison group and compared the covariate means after matching between the two groups. We found that the standardized differences between treatment and comparison for all covariate means were within 0.25 .

We found that the covariates for the biological sciences college, science and engineering college, Asian/Pacific Islander race category, and American Indian race category exceeded the WWC (2017)recommended 0.05 standard mean differences between treatment and comparison groups that would allow us to ignore differences and that those between 0.05 must be statistically adjusted for. Thus, we included variables as covariates in the regression analysis where differences still existed in a range between 0.05 and 0.25 standardized mean differences (see Appendix B for pairwise correlation table between these covariates and outcome and treatment variables). Their inclusion means that the individual regression weights were partial regression coefficients rather than simple regression coefficients for the treatment variable. 


\section{Results}

Table 1 presents the results of all students' cumulative GPA, cumulative credits earned, retention, and graduation status across all cohorts from regression analyses. As noted above, these regression analyses included covariates: enrollment in biological sciences college, science and engineering college, Asian or Pacific Islander background, and American Indian background.

Table 1

Partial Regression Coefficients for the Relationship Between Community-Engaged Employment and Academic Outcomes for Underrepresented Students $(N=432)$

\begin{tabular}{lllllllll}
\hline & GPA & \multicolumn{4}{c}{ Credits Earned } & \multicolumn{2}{c}{ Retention } & \multicolumn{2}{c}{ Graduation } \\
\cline { 2 - 8 } & $B$ & $S E$ & $B$ & $S E$ & $B$ & $S E$ & $B$ & $S E$ \\
\hline Participation & $0.24^{* * *}$ & 0.06 & $19.6^{* * *}$ & 3.5 & $.12^{* * *}$ & 0.03 & $.16^{* * *} 0.05$
\end{tabular}

Note. Controlling for initial enrollment in biological sciences college and engineering college, and for Asian or Pacific Islander, and American Indian backgrounds. $* * * \mathrm{p}<.001$.

\section{Differences in Academic Enrollment Status Within 6 Years}

We tested three possible outcomes for students' enrollment: second year retention, graduated, and withdrawn by the end of 6 years. Although not all cohorts would have had the same number of years to possibly withdraw or graduate, because we used exact matching for entry term, the students were compared only with others who had the same amount of time for enrollment. Using a generalized linear model, we analyzed whether there were differences between the treatment and comparison groups in terms of graduation rates and withdrawal rates, while controlling for any of the variables still showing differences between 0.05 and 0.25 standardized mean differences as mentioned above (i.e., biological sciences college, engineering college, Asian, and American Indian).

Second-Year Retention. We first looked at second-year retention. This would allow us to compare across entry terms because included cohorts would have had at least 2 years of enrollment status. Specifically, we analyzed whether students who participated in the program during their first year were more likely to stay enrolled during their second year. Controlling for the covariates, participants were significantly more likely to be enrolled for their second year than their matched peers $(\mathrm{OR}=1.19, t(431)=$ $3.7, p<.001)$. Among the matched students, $91.7 \%$ of participants and $79.2 \%$ of nonparticipants were still enrolled by the end of their second year.

Graduation. When controlling for the four covariates mentioned earlier, we found first-year participation in the community-engaged employment experience was significantly positively related to graduation rates within 6 years $(\mathrm{OR}=1.18, t(431)=3.51, p<.001)$. Among the matched students, $52.8 \%$ of those who participated graduated within 6 years, whereas $38 \%$ of nonparticipants graduated within 6 years. For those who were enrolled in 2010 or 2011 ( $n=182$; allowing for at least 6 years of data), 89\% of participants graduated, compared to $64.8 \%$ of nonparticipants. For students first enrolled in 2012-2015 ( $n$ $=250$ ), $26.4 \%$ of participants and $18.4 \%$ of nonparticipants graduated. Regardless of term of entry and controlling for the effects of the covariates, participants were more likely to graduate within 6 years than those who did not participate.

Withdrawing. Controlling for these same covariates, participation was significantly negatively related to having withdrawn within the first 6 years $(\mathrm{OR}=0.85, t(431)=-3.52, p<.001)$. For the entire matched sample, $10.2 \%$ of participants, versus $22.7 \%$ of nonparticipants, withdrew. For those who had at least 6 years of data $(n=182), 9.9 \%$ of participants, versus $30.8 \%$ of nonparticipants, withdrew. For those who had fewer than 6 years of data $(2.5-5.5$ years since initial enrollment; $n=250), 10.4 \%$ of participants and $16.8 \%$ of nonparticipants had withdrawn by the time of data collection. When compared to those who had 
the same possible number of years of enrollment, nonparticipants were more likely to have dropped out than participants, when controlling for the effects of the covariates.

\section{Grade Point Average (GPA)}

We assessed whether there were significant differences between students' GPA during their last semester of enrollment (i.e., the semester they graduated, the latest possible data, or the semester before withdrawing). Although not all cohorts would have had the same number of years to earn grades that would impact their GPA, because students were exact matched on entry term, they were compared only with others who had the same amount of time to earn grades. Participation was found to be significantly related to final, cumulative GPA, above and beyond the effects of unbalanced covariates $(B=0.24, t(425)=3.9, p<.001)$. Of the matched sample, participants had an average GPA of $3.21(\mathrm{SD}=0.49)$ whereas nonparticipants had an average GPA of $2.96(\mathrm{SD}=0.77)$.

\section{Cumulative Credits Completed}

Lastly, we looked at the final total credits completed by students during their last semester of enrollment. As mentioned earlier, while not all cohorts would have had the same number of years to earn credits, because we used exact matching for entry term, the students were compared only with others who had the same amount of time to earn credits. Participation was significantly related to final credits completed when controlling for the effects of the unbalanced covariates $(B=19.51, t(425)=5.56, p<.001)$. (Because more students in comparison group did not graduate, their number of cumulative credits earned is substantially less than the treatment group.) Controlling for the effects of whether they were in the biological sciences or engineering colleges and Asian or American Indian, participants completed, on average, more credits by their final term of enrollment than their matched peers. Of the matched sample, participants completed an average of $118.61(\mathrm{SD}=32.31)$ credits compared to an average of $99.38(\mathrm{SD}=40.91)$ credits for nonparticipants. For those who had at least 6 years of data $(n=182)$, participants completed an average of $132.64(\mathrm{SD}=41.05)$ whereas nonparticipants completed an average of $105.82(\mathrm{SD}=48.23)$ credits.

Overall, participation in first-year community-engaged employment opportunity was related to higher second-year retention rates, higher graduation rates, lower withdrawal rates, higher cumulative GPAs, and higher cumulative credits completed.

\section{Discussion}

We investigated whether underrepresented college students who participated in community-engaged employment demonstrated better academic outcomes (i.e., higher GPA, greater persistence, more cumulative credits earned, and higher graduation rates) compared to their peers who were not employed in the same program. The results argue that community-engaged employment can improve academic outcomes for underrepresented college students. We found that underrepresented students who participated as paid mentors or tutors for diverse community youth were more likely to stay enrolled, earned significantly higher GPAs as well as more credits, and had higher graduation rates than their matched peers who did not participate as paid mentors or tutors. These results suggest that this type of community-engaged employment contributed to improved academic outcomes for participating underrepresented students. Our conclusions are further strengthened by the lengths we took to address selection bias. We controlled for the differences between the participants and nonparticipants by creating a matched comparison group where the participants were paired with nonparticipants having similar background characteristics.

The relationship between paid community engagement and higher persistence, GPA, retention, and graduation found in the present study is consistent with previous research on volunteer engagement (Celio et al., 2011; Gallini \& Moely, 2003; Lockeman \& Pelco, 2013; Reed et al., 2015; Song et al., 2017; Warren, 2012; Yorio \& Ye, 2012). The findings also support our hypothesis that participation in communityengaged employment can encourage the academic success of underrepresented students. Further, our findings suggest that community-engaged employment can provide academic benefits similar to those of 
volunteer community engagement while also providing a source of income, which is especially important for underrepresented students who are more likely to have multiple obligations outside of school (Engle \& Tinto, 2008). Low-income students may not be able to participate in volunteer community engagement experiences due to employment obligations or other barriers. However, if their job could provide community engagement experiences, they would not have to further divide their time and resources, which makes community-engaged employment a practical alternative to volunteer community engagement.

Current findings may help to explain previous research that reported some negative relationships between community service experiences and underrepresented students' educational success (e.g., Reed et al., 2015; Song et al., 2017). While volunteer engagement opportunities may help non-underrepresented students create connections between their education and civic reasonability, the same experiences may create more academic challenges for underrepresented students. For example, for some students, the time required for volunteer service might be borrowed from the time they set aside to do their homework. Because of other time commitments (e.g., job obligations, commuting, family care), there may be no extra time to dedicate to their academic work, and, therefore, their academic performance could suffer. Community-engaged employment allows underrepresented students to get the experiences of community service without extra time burdens. In this way, it serves two purposes for underrepresented students: it supports their academic success, and it provides a needed source of income.

These findings also support our conceptual predictions that community-engaged employment can result in outcomes similar to those found in the community engagement literature. Based on Bean and Eaton's (2001) framework, we predicted that community-engaged employment could provide the context that helps students cultivate the skills and relationships that lead to better social and academic integration and, ultimately, help determine their retention outcomes. While we did not investigate the particular psychological processes outlined in this model, we theorize that the pattern of improved academic results found in this study were, at least in part, due to skills and behaviors learned through community-engaged employment. Moreover, our findings were consistent with Bronfenbrenner's (1994) framework, which suggests that, by creating connections between different environments, such as by mentoring youth from the community, college students can better make sense of their complete lives. Through their mentoring and tutoring experiences, college students can find connections between their different environments, thereby providing the overlap needed to help them understand how their college environment fits with and complements their community environment.

Importantly, our sample of students was in their first year of college. These students were significantly more likely to reenroll for their second year, compared to students who were not participating in community-engaged employment. Our findings support prior research on community service experiences, which found that reenrollment for the second year was related to participation in a community service course (Bringle et al., 2010). Such meaningful experiences early in students' college career are likely to provide positive interactions associated with their new environment - spurring a feedback loop of attitudes and productive behaviors that influence their academic success (Bean \& Eaton, 2001). For underrepresented students who often have fewer opportunities to make genuine connections between their community and college environment because of time and financial barriers (Soria et al., 2014), community-engaged employment could offer a practical and effective solution. Importantly, the community partner's support for the students also provided them with a network of peers with whom they could interact and discuss their experiences, providing another parallel to community engagement programs like service-learning.

While the present study is among the first to examine off-campus community-engaged employment, parallels may exist between this type of work and some campus-based employment. For example, Barnhardt and colleagues (2019) examined the effects of on-campus jobs for college students that provided relevant and meaningful work experiences, aligned with their academic interest, and had a deliberate emphasis on reflection. Barnhardt et al. found that these jobs increased students' civic commitment. Wilkie and Jones (1994) looked at on-campus employment that was highly structured, matched with students' interests, and promoted personal and job-related growth. They found students who worked these jobs 8 hours per week throughout their first year in college had higher academic achievement and higher retention rates, compared to those who worked fewer hours or not at all. Pike et al. (2008) found that first-year students who worked 
in on-campus jobs that were related to higher engagement scores (reported from the National Survey of Student Engagement) reported higher grades, compared to those who worked other jobs that were not related to high engagement scores. Altogether, it appears that community-engaged employment shares characteristics, and provides some similar benefits, with some types of campus-based employment. Although these types of jobs are similar, it is important to note that, for underrepresented students, community-engaged employment uniquely promotes positive connections between the students' community and the college environment.

\section{Limitations and Future Research Directions}

To increase our sample size, we aggregated multiple student cohorts in our outcome analyses, which resulted in unequal timeframes when evaluating academic retention and credits earned. For example, we evaluated the status of academic retention for the 2011 cohort for their 6th year, compared to the 2015 cohort's second year (our last available year of data was 2017). To address any biases that could arise from this, including students from different cohorts who have unmatched total number of years of enrollment, we ensured that a participant from any given cohort (e.g., one who entered in 2012) was matched only with a nonparticipant from the same cohort (e.g., also entered in 2012). Such a matching step allowed us to assume a stable unit treatment value and draw stronger conclusions regarding the effects of the communityengaged employment on academic retention, graduation, and cumulative credits earned across multiple cohorts.

Furthermore, as is true for any study using propensity score matching, although matching in our study seemed very good, it is possible that despite our substantial number of meaningful matching variables and covariates, other extraneous variables that were uncontrolled might have produced differences between the two groups above and beyond the effect of participation. Future research on this practice ideally would include randomized studies looking at different types of community-engaged employment and measuring students' sense of belonging, academic self-efficacy, and attitudes toward their academic institution before and after these experiences.

In closing, many underrepresented students might feel the culture on campus to be foreign and the academic content to lack relevancy. By working with community members in meaningful ways outside the university, students can find a connection between their coursework and their experiences in the local community. Such experiences also likely nurture valuable social networks and foster a sense of belonging that might be absent when students are not engaged or do not feel integrated on their college campus. Community-engaged employment addresses the unique barriers that underrepresented students encounter and serves as a promising practice to bolster their undergraduate academic success.

\section{Conclusion}

In conclusion, our findings show that community-engaged employment can offer more than just financial support to college students by providing experiences that increase academic success and help students thrive in college. Off-campus employment designed to foster connections between the college environment and the local community can help colleges and community partners better support underrepresented students' academic journeys.

\section{References}

Altman, I. (1996). Higher education and psychology in the millennium. American Psychologist, 51(4), 371378. https://doi.org/10.1037/0003-066X.51.4.371

Astin, A. W., Vogelgesang, L. J., Ikeda, E. K., \& Yee, J. A. (2000). How service learning affects students. UCLA, Higher Education Research Institute. http://digitalcommons.unomaha.edu/slcehighered/144?utm_source=digitalcommons.unomaha.ed $\underline{\mathrm{u} \% 2 \text { Fslcehighered } \% 2 \mathrm{~F} 144 \& u t m \text { medium }=\mathrm{PDF} \& u t m \_ \text {campaign=PDFCoverPages }}$ 
Austin, P. C. (2011). A tutorial and case study in propensity score analysis: An application to estimating the effect of in-hospital smoking cessation counseling on mortality. Multivariate Behavioral Research, 46(1), 119-151. https://doi.org/10.1080/00273171.2011.540480

Barnhardt, C. L., Trolian, T., An, B., Rossmann, P. D., \& Morgan, D. L. (2019). Civic learning while earning? The role of student employment in cultivating civic commitments and skills. The Review of Higher Education, 42(2), 707-737. https://doi.org/10.1353/rhe.2019.0012

Bean, J., \& Eaton, S. B. (2001). The psychology underlying successful retention practices. Journal of College Student Retention: Research, Theory \& Practice, 3(1), 73-89. https://doi.org/10.2190/6R55-4B30-28XG-L8U0

Berger, J. B., \& Milem, J. F. (2002). The impact of community service involvement on three measures of undergraduate self-concept. NASPA Journal, 40(1), 85-103. https://doi.org/10.2202/19496605.1190

Bringle, R. G., Hatcher, J. A., \& Muthiah, R. N. (2010). The role of service-learning on the retention of first-year students to second year. Michigan Journal of Community Service Learning, 16(2), 3849. http://hdl.handle.net/1805/9646

Bringle, R. G., \& Steinberg, K. (2010). Educating for informed community involvement. American Journal of Community Psychology, 46(3-4), 428-441. https://doi.org/10.1007/s10464-010-9340-y

Bronfenbrenner, U. (1994). Ecological models of human development. The International Encyclopedia of Education, 3(2), 1643-1647.

Celio, C. I., Durlak, J., \& Dymnicki, A. (2011). A meta-analysis of the impact of service-learning on students. Journal of Experiential Education, 34(2), 164-181. https://doi.org/10.5193/JEE34.2.164

Cooper, J. G., Kotval-K, Z., Kotval Z., \& Mullin, J. (2014). University community partnerships. Humanities, 3(1), 88-101. https://doi.org/10.3390/h3010088

Engle, J., \& Tinto, V. (2008). Moving beyond access: College success for low-income, first-generation students. Pell Institute for the Study of Opportunity in Higher Education.

Figueroa, T., \& Hurtado, S. (2014, November 19-22). Adjustment to the graduate environment: A focus on URM students in STEM [Conference breakout]. 39th Annual Conference, Association for the Study of Higher Education, Washington, DC.

Fitzgerald, H. E., Bruns, K., Sonka, S. T., Furco, A., \& Swanson, L. (2016). The centrality of engagement in higher education: Reflections and future directions. Journal of Higher Education Outreach and Engagement, 20(1), 245-254.

Gallini, S. M., \& Moely, B. E. (2003). Service-learning and engagement, academic challenge, and retention. Michigan Journal of Community Service Learning, 10(1), 5-14. http://hdl.handle.net/2027/spo.3239521.0010.101

Hansen, B. B., \& Klopfer, S. O. (2006). Optimal full matching and related designs via network flows. Journal of Computational and Graphical Statistics, 15(3), 609-627.

Harder, V. S., Stuart, E. A., \& Anthony, J. C. (2010). Propensity score techniques and the assessment of measured covariate balance to test causal associations in psychological research. Psychological Methods, 15(3), 234-249. https://doi.org/10.1037/a0019623

Ho, D., Imai, K., King, G., \& Stuart, E. (2011). MatchIt: Nonparametric preprocessing for parametric causal inference. Journal of Statistical Software, 42(8). http://dx.doi.org/10.18637/jss.v042.i08

Holliday, M. L., DeFalco, T., \& Sherman, J. D. B. (2015). Putting impact first: Community-university partnerships to advance authentic neighborhood sustainability. Curricular Innovation, 26(3). http://journals.iupui.edu/index.php/muj/article/view/21107/20512

Hollister, R. M., Wilson, N., \& Levine, P. (2008). Educating students to foster active citizenship. Peer Review, 10(2/3), 18-21.

Hurtado, S., Carter, D., \& Spuler, A. (1996). Latino student transition to college: Assessing difficulties and factors in successful college adjustment. Research in Higher Education, 37(2), 135-157. http://dx.doi.org/10.1007/BF01730113 
Hurtado, S., \& Carter, D. F. (1997). Effects of college transition and perceptions of the campus racial climate on Latino college students' sense of belonging. Sociology of Education, 70(4), 324-345. https://doi.org/10.2307/2673270

Johnson, J. (2018). jasonrpro: Propensity score matching $r$ functions $R$ package (Version 2). Retrieved August 14, 2020, from https://github.com/jasonrpro/

Kuh, G. D., Kinzie, J., Schuh, J. H., Whitt, E. J., \& Associates (2005). Student success in college: Creating conditions that matter. Jossey-Bass.

Levine, A., \& Cureton, J. (1998). When hope and fear collide: A portrait of today's college student. JosseyBass.

Lockeman, K. S., \& Pelco, L. E (2013). The relationship between service-learning and degree completion. Michigan Journal of Community Service Learning, 20(1), 18-30. https://files.eric.ed.gov/fulltext/EJ1047041.pdf

Longwell-Grice, R., \& Longwell-Grice, H. (2007-2008). Testing Tinto: How do retention theories work for first-generation, working-class students? Journal of College Student Retention, 9(4), 407-420. http://dx.doi.org/10.2190/CS.9.4.a

Martinez, J. A., Sher, K. J., Krull, J. L., \& Wood, P. K. (2009). Blue-collar scholars? Mediators and moderators of university attrition on first-generation students. Journal of College Student Development, 50(1), 87-103. http://dx.doi.org/10.1353/csd.0.0053

Maurrasse, D. J. (2002). Beyond the campus: How colleges and universities form partnerships with their communities. Routledge.

Palmer, P. J. (2007) A new professional: The aims of education revisited. Change: The Magazine of Higher Learning, 39(6), 6-13. https://doi.org/10.3200/CHNG.39.6.6-13

Pike, G. R., Kuh, G. D., \& Massa-McKinley, R. C. (2008). First-year students' employment, engagement, and academic achievement: Untangling the relationship between work and grades. NASPA Journal, 45(4), 560-582. https://doi.org/10.2202/1949-6605.2011

McFarland, J., Hussar, B., Zhang, J., Wang, X., Wang, K., Hein, S., \& Purcell, S. (2019). The condition of education. U.S. Department of Education.

Mesch, D. J., Tschirhart, M., Perry, J. L., \& Lee, G. (1998). Altruists or egoists? Retention in stipended service. Nonprofit Management and Leadership, 9(1), 3-22. https://doi.org/10.1002/nml.9101

Pittman, L. D., \& Richmond, A. (2008). University belonging, friendship quality, and psychological adjustment during the transition to college. Journal of Experimental Education, 76(4), 343-361. https://doi.org/10.3200/JEXE.76.4.343-362

Reed, S. C., Rosenberg, H., Statham, A., \& Rosing, H. (2015). The effect of community service learning on undergraduate persistence in three institutional contexts. Michigan Journal of Community Service Learning, 21(2), 22-36. http://hdl.handle.net/2027/spo.3239521.0021.202

Rosenbaum, P. R. (2010). Design of observational studies. Springer.

Sandy, M., \& Holland, B. (2006). Different worlds and common ground: Community partner perspectives on campus-community partnerships. Michigan Journal of Community Service Learning, 13(1). http://hdl.handle.net/2027/spo.3239521.0013.103

Schamber, J. F., \& Mahoney, S. L. (2008). The development of political awareness and social justice citizenship through community-based learning in a first-year general education seminar. Journal of General Education, 57(2), 75-99.

Sekhon, J. (2011). Multivariate and propensity score matching software with automated balance optimization: The matching package for R. Journal of Statistical Software, 42(7), 1-52. http://dx.doi.org/10.18637/jss.v042.i07

Song, W., Furco, A., Lopez, I., \& Maruyama, G. (2017). Examining the relationship between servicelearning participation and the educational success of underrepresented students. Michigan Journal of Community Service Learning, 24(1), 23-37.

Soria, K. M. (2015). Welcoming blue collar scholars into the ivory tower: Developing class conscious strategies for students' success. National Resource Center for the First-Year Experience and Students in Transition. 
Soria, K. M., Troisi, J. N., \& Stebleton, M. J. (2012). Reaching out, connecting within: Community service and sense of belonging among college students. Higher Education in Review, 9, 65-85.

Soria, K. M., Nobbe, J., \& Fink, A. (2013). Examining the intersections between undergraduates' engagement in community service and development of socially responsible leadership. Journal of Leadership Education, 12(1), 117-140. http://hdl.handle.net/11299/150281

Soria, K. M., Weiner, B., \& Lu, E. C. (2014). Financial decisions among undergraduate students from lowincome and working-class social class backgrounds. Journal of Student

Financial Aid, 44(1), Art. 2. https://ir.library.louisville.edu/jsfa/vol44/iss1/2

Steele, C. M., \& Aronson, J. (1995). Stereotype threat and the intellectual test performance of African Americans. Journal of Personality and Social Psychology, 69(5), 797-811. https://doi.org/10.1037/0022-3514.69.5.797

Steinberg, K., Hatcher, J., \& Bringle, R. 2011. Civic-minded graduate: A north star. Michigan Journal of Community Service Learning, 18(1), 19-33.

Stuart, E. A. (2010). Matching methods for causal inference: A review and a look forward. Statistical science: A review journal of the Institute of Mathematical Statistics, 25(1), 1-21. https://doi.org/10.1214/09-STS313

Strier, R. (2010). The construction of university-community partnerships: Entangled perspectives. Higher Education, 62(1), 81-97. https://doi.org/10.1007/s10734-010-9367-x

Suarez-Balcazar, Y., Harper, G. W., \& Lewis, R. (2005). An interactive and contextual model of community-university collaborations for research and action. Health Education \& Behavior, 32(1), 84-101. https://doi.org/10.1177/1090198104269512

Ting, S. R. (2000). Predicting Asian Americans' academic performance in the first year of college: An approach combining SAT scores and non-cognitive variables. Journal of College Student Development, 41(4), 442-449.

Tschirhart, M., Mesch, D. J., Perry, J. L., Miller, T. K., \& Lee, G. (2001). Stipended volunteers: Their goals, experiences, satisfaction, and likelihood of future service. Nonprofit and Voluntary Sector Quarterly, 30(3), 422-443.

Vang, C. T. (2005). Hmong-American students still face multiple challenges in public schools. Multicultural Education, 13(1), 27-35.

Walton, G. M., \& Cohen, G. L. (2007). A question of belonging: race, social fit, and achievement. Journal of Personality and Social Psychology, 92(1), 82-96. https://doi.org/10.1037/0022-3514.92.1.82

Warren, M. (2005). Communities and schools: A new view of urban education reform, Harvard Educational Review, 75(2), 133-173.

Warren, J. L. (2012). Does service-learning increase student learning? A meta-analysis. Michigan Journal of Community Service Learning, 18(2), 56-61.

Weiler, L., Haddock, S., Zimmerman, T. S., Krafchick, J., Henry, K., \& Rudisill, S. (2013). Benefits derived by college students from mentoring at-risk youth in a service-learning course. American Journal of Community Psychology, 52(3-4), 236-248. https://doi.org/10.1007/s10464-013-9589-z

What Works Clearinghouse. (2017). Standards handbook (Version 4.0). https://ies.ed.gov/ncee/wwc/Docs/referenceresources/wwc_standards_handbook_v4.pdf

Wilkie, C., \& Jones, M. (1994). Academic benefits of on-campus employment to first-year developmental education students. Journal of The First-Year Experience \& Students in Transition, 6(2), 37-56.

Yorio, P. L., \& Ye, F. (2012). A meta-analysis on the effects of service-learning on the social, personal, and cognitive outcomes of learning. Academy of Management Learning \& Education, 11(1), 9-27. https://doi.org/10.5465/amle.2010.0072

Yue, H., \& Hart, S. M. (2017). Service-learning and graduation: Evidence from event history Analysis. Michigan Journal of Community Service Learning, 23(2), 24-41. http://dx.doi.org/10.3998/mjcsloa.3239521.0023.202

Zlotkowski, E., \& Duffy, D. (2010). Two decades of community-based learning. New Directions for Teaching and Learning, 123, 33-43. https://doi.org/10.1002/tl.407 


\section{Appendix A}

Logistic Regression Predicting Likelihood of Participation in Community-Engaged Employment Program Based on Term of Enrollment, Citizenship Status, Race, Prior Achievement, College, Honors, SES, Age, Sex, and First-Generation Status

\begin{tabular}{lcccccc}
\hline & $B$ & S.E. & Wald & $d f$ & $p$ & Odds Ratio \\
\hline Fall 2010 & -.904 & .215 & 17.684 & 1 & $.000^{* * *}$ & .405 \\
Fall 2011 & 1.950 & .484 & 16.263 & 1 & $.000^{* * *}$ & 7.031 \\
Fall 2012 & 1.096 & .353 & 9.636 & 1 & $.002^{* *}$ & 2.992 \\
Fall 2013 & -.040 & .250 & .026 & 1 & .873 & .961 \\
Fall 2014 & -.394 & .232 & 2.873 & 1 & .090 & .675 \\
Citizen & -.831 & 1.015 & .670 & 1 & .413 & .436 \\
Asian/Pacific Islander & -.498 & .180 & 7.612 & 1 & $.006 * *$ & .608 \\
Black & -.961 & .211 & 20.818 & 1 & $.000^{* * *}$ & .382 \\
Hispanic & -.443 & .299 & 2.191 & 1 & .139 & .642 \\
American Indian & -.400 & .471 & .722 & 1 & .396 & .670 \\
Prior Achievement & -.035 & .025 & 1.930 & 1 & .165 & .966 \\
Liberal Arts college & -.085 & .323 & .069 & 1 & .793 & .919 \\
Education college & -.636 & .349 & 3.318 & 1 & .069 & .529 \\
Biology college & -.350 & .407 & .740 & 1 & .390 & .705 \\
Management college & .159 & .478 & .112 & 1 & .738 & 1.173 \\
Science college & .037 & .421 & .008 & 1 & .931 & 1.037 \\
Design college & 1.250 & .773 & 2.617 & 1 & .106 & 3.490 \\
Honors & .387 & .524 & .544 & 1 & .461 & 1.472 \\
Sex & -.855 & .165 & 26.691 & 1 & $.000 * * *$ & .425 \\
SES (Pell) & -.468 & .165 & 8.029 & 1 & $.005^{* * *}$ & .626 \\
Age & -.104 & .133 & .614 & 1 & .433 & .901 \\
First-generation & -.316 & .154 & 4.209 & 1 & $.040^{*}$ & .729 \\
Constant & -1.524 & 3.371 & .204 & 1 & .651 & .218 \\
\hline & & & & & 1 \\
\hline
\end{tabular}

Note: Fall 2015 enrollment, agricultural college, and White race are reference categories. ${ }^{* * *} p<.001,{ }^{* *} p<.01$, $* p<.05$. 


\section{Appendix B}

Pairwise Correlations for Outcome Variables and Covariates Included in Outcome Analyses

\begin{tabular}{|c|c|c|c|c|c|c|c|c|c|c|}
\hline & 1. & 2. & 3. & 4. & 5. & 6. & 7. & 8. & 9. & 10. \\
\hline 1. Asian & 1 & & & & & & & & & \\
\hline 2. Am. Indian & -.085 & 1 & & & & & & & & \\
\hline 3. Biology college & .014 & .030 & 1 & & & & & & & \\
\hline 4. Engineering college & -.061 & -.026 & -.052 & 1 & & & & & & \\
\hline 5.2nd-year retention & .000 & .051 & -.007 & .033 & 1 & & & & & \\
\hline 6. Graduation & $-.098^{*}$ & -.056 & -.066 & $.183^{* *}$ & $.337^{* *}$ & 1 & & & & \\
\hline 7. Withdraw & -.010 & -.061 & -.023 & -.050 & $-.687^{* *}$ & $-.404^{* *}$ & 1 & & & \\
\hline 8. GPA & $-.125^{* *}$ & .048 & $.119^{*}$ & -.047 & $.467^{* *}$ & $.258^{* *}$ & $-.502^{* *}$ & 1 & & \\
\hline 9. Credits & -.014 & -.016 & .055 & $.184^{* *}$ & $.491^{* *}$ & $.762^{* *}$ & $-.539^{* *}$ & $.460^{* *}$ & 1 & \\
\hline 10. Treatment & .041 & .034 & .036 & -.038 & $.178^{* *}$ & $.149^{* *}$ & $-.169^{* *}$ & $.186^{* *}$ & $.233^{* *}$ & 1 \\
\hline
\end{tabular}

Note: $* p<0.05, * * p<0.01$. 


\begin{abstract}
About the Authors
Anthony J. Schulzetenberg is a post-doctoral fellow in the Center for Behavioral Science Methods at the U.S. Census Bureau (DC, USA).

Yu-Chi Wang is a doctoral candidate in the Department of Educational Psychology at the University of Minnesota-Twin Cities (MN, USA).

Ashley S. Hufnagle is a doctoral student in the Department of Educational Psychology at the University of Minnesota-Twin Cities (MN, USA).

Krista M. Soria is director of student affairs assessment at the University of Minnesota -Twin Cities (MN, USA).

Geoffrey Maruyama is professor and chair of the Department of Educational Psychology at the University of Minnesota-Twin Cities (MN, USA).

Jason Johnson is a researcher in the Center for Applied Research and Education Improvement at the University of Minnesota-Twin Cities (MN, USA).

Correspondence concerning this article should be addressed to Anthony J. Schulzetenberg at schu2856@umn.edu.
\end{abstract}

